\title{
Plant Harvesting Impacts on Soil Water Patterns and Phenology for Shrub-encroached Grassland
}

\author{
Ying Fan ${ }^{1,2,3}\left(\mathbb{D}\right.$, Xiao-Yan $\mathrm{Li}^{1,2, *} \mathbb{1}$, Liu Li ${ }^{1,2}$, Jun-Qi Wei ${ }^{1,2}$, Fang-Zhong Shi ${ }^{1,2}$, \\ Hong-Yun Yao ${ }^{1,2}$ and Lei Liu ${ }^{1,2}$ \\ 1 State Key Laboratory of Earth Surface Processes and Resource Ecology, Faculty of Geographical Science, \\ Beijing Normal University, Beijing 100875, China; fanying@mail.bnu.edu.cn (Y.F.); lhataki@163.com (L.L.); \\ jq_wei@mail.bnu.edu.cn (J.-Q.W.); 201521190016@mail.bnu.edu.cn (F.-Z.S.); \\ hyyao@mail.bnu.edu.cn (H.-Y.Y.); 1liu526@mail.bnu.edu.cn (L.L.) \\ 2 School of Natural Resources, Faculty of Geographical Science, Beijing Normal University, \\ Beijing 100875, China \\ 3 Department of Environmental Science, Policy, and Management, University of California at Berkeley, \\ CA 94720 , USA \\ * Correspondence: xyli@bnu.edu.cn; Tel.: +86-10-5880-2716
}

Received: 30 April 2018; Accepted: 29 May 2018; Published: 5 June 2018

\begin{abstract}
Harvesting is a common method in grassland management. With shrub encroachment into grassland, special hydrological and physiological dynamics probably occur in the shrub-grass coexisted ecosystem after harvesting, which remains largely unclear. Therefore, this study aims to identify potential effects of harvesting on soil moisture pattern, phenology dynamics, and water utilization in a shrub encroached grassland. We monitored soil water for a year beneath the Caragana microphylla canopy and interspace grassland after harvesting. The results showed that the soil water content increased under shrubs and grass patches after harvesting, especially under later ones. The water storage in soil of $0-100 \mathrm{~cm}$ depth increased by $18.9 \mathrm{~mm}$ under grass but only $5.5 \mathrm{~mm}$ under shrubs. Harvesting also decreased the difference of water storage between shrubs and grass from 19.1 to $5.7 \mathrm{~mm}$. More snowmelt compensation, less evapotranspiration, shorter growing season, and higher water use efficiency may jointly contribute to the water recovery of harvesting soil. This study contributes novel evidence to the ecohydrological impacts of harvesting on shrub-grass co-existed ecosystems, shows application value in controlling shrub encroachment process and provides fundamental insights for the further study on soil water dynamics of similar ecosystems worldwide.
\end{abstract}

Keywords: Caragana microphylla; soil moisture; water use source; water use efficiency; shrub removal

\section{Introduction}

Harvesting, a common method in grassland, shrubland, and forest, has a long history in the pastoral area [1]. People harvested excess plants to balance the contradiction between the supply and demand of livestock feed. The physical environment changed after harvesting, in such ways as an increased daylight intensity, temperature, and evaporation rate, leading to further changes in vegetation composition and species diversity [2-5]. Shrub encroachment is a global phenomenon associated with marked changes in ecosystem structure and function over the past 100-150 years [6-8]. In shrub-grass coexisted ecosystems, previous studies mainly focused on the restoration process after shrub clearing, such as coverage, species changes, biomass, tiller number, and nutrient regime etc. [9-14]. Many of these studies have a common purpose on whether communities could be restored to grassland after harvesting, alleviating, or reversing the encroachment trends of shrubs into grasslands. Some of 
them have proved that shrub removal facilitates grassland recovery $[9,10,15-17]$. Thus, a periodical cutting every five or six years is suggested before shrub increases to a certain coverage (for example, 30\%) in order to stimulate more grasses [10,18].

However, as a critical indicator of underground processes, soil moisture dynamics have not got much attention after harvesting in shrub encroached grassland. In these ecosystems, inter-canopy patches can be regarded as the source due to high runoff, while shrub patches are regarded as the sink, which is also known as "hydrologic islands" [19]. Specifically, greater and deeper infiltration is observed beneath Caragana microphylla canopy than interspace grass, and soil hydraulic conductivity for shrub is 2-3 times those of the grass here in the Inner Mongolian grassland [20-22]. These traits could be altered by harvesting activities, which directly reduce vegetation cover, change physical environment, and even harden the soil surface with a large harvester machine. In semiarid rangeland, $17 \%$ more water penetrates to the deep soil layer and groundwater recharge increases by $2.59 \pm 1.7 \mathrm{~mm} \cdot \mathrm{year}^{-1}$ after shrub removal [23]. In sagebrush rangeland, the overall water supply is enhanced by about $6 \mathrm{~cm}$ after burning woody vegetation [24]. Removing woody plants is a common practice to enhance water supply in semiarid rangelands of the USA [24]. In some cases, the removal of grasses also creates enhanced soil water content and the increased soil water potential at the depth of 0 to $60 \mathrm{~cm}$ [25]. Moreover, shrubs need about decades to recover from harvesting, which is much slower than pure grassland [26,27]. Changes in plants cover, canopy structure, and topography could persist for years, and influence rainfall interception, infiltration, evapotranspiration, and runoff [28-30]. These small alterations in hydrological processes can accumulate over time, leading to lasting effects on shrub encroached grassland. Therefore, special and complex soil moisture dynamics probably occur after harvesting in this shrub-grass coexisted ecosystem.

It would be interesting to understand the physiological process of shrub-grass interaction when plants are harvested. Misson et al. [31] found that understory shrub harvesting directly reduced the leaf area index and canopy photosynthesis but did not affect ecosystem respiration, making the system from a carbon sink to a source in the restoration period., whereas the nitrogen content in the leaves of the shrubs and grasses is not significantly changed after removal [25]. Coexisted shrub and grass could also interplay after harvesting. Grass removal alone results in a significant increase in shrub production and leaf water potential [25]. The water use efficiency of shrubs increases after clearing them, the same for grasses [31,32]. However, water use efficiency (WUE) changes of shrub-grass coexisted ecosystems were unclear. Phenophase may also respond to plant harvesting due to its correlation with soil moisture in water-limited regions [33-35]. In feedbacks, plant phenology could affect soil water consumption by determining the time span of plant water uptake. Therefore, the responses of the WUE, phenology, and water uptake fraction to harvesting activity are worth exploring under the shrub-grass coexisted ecosystems.

Therefore, the objective of this study was to identify potential impacts of harvesting on soil water dynamics, combined with accompanying changes in phenology, water use source, and efficiency in a shrub encroached grassland community. This work contributes novel evidence to the ecohydrological impacts of harvesting on the shrub-grass co-existed ecosystems and would be important for the management of shrub-encroached grassland.

\section{Field Experiments and Methods}

\subsection{Study Area}

This experiment was conducted at the Farmland and Grassland Ecosystem Observation Station of Beijing Normal University $\left(115^{\circ} 27^{\prime} \mathrm{E}, 42^{\circ} 08^{\prime} \mathrm{N}\right)$, located in Taipus Banner, Inner Mongolia, in Northern China. Our study site is situated at a $1400 \mathrm{~m}$ elevation. The study area has a temperate continental semiarid climate which is characterized as mild and rainy in summer, and cold and dry in winter. Meteorological observations in the experimental site (June 2015 to May 2016) showed that the daily air temperature was $3.3^{\circ} \mathrm{C}$ with a maximum of $23.8^{\circ} \mathrm{C}$ and minimum of $-32.4{ }^{\circ} \mathrm{C}$. Based on 
55-year meteorological records (1956-2011), the mean annual temperature is $2.7^{\circ} \mathrm{C}$, with a maximum monthly temperature of $17.8^{\circ} \mathrm{C}$ (July) and a minimum monthly temperature of $-17.6^{\circ} \mathrm{C}$ (January). The mean annual precipitation is $322 \mathrm{~mm}$ with $65 \%$ occurring from July to September. The mean annual pan evaporation amounts to $1900 \mathrm{~mm}$. The zonal soils are chestnut and light chestnut, which are equivalent to Calcic-orthic Aridisol according to the Soil Taxonomy of United States Department of Agriculture [36]. In the soil profile, caliche resulting from the dissolving and leaching of $\mathrm{CaCO}_{3}$ by rainwater is commonly found in the form of either nodules or layers. The soil profile is stratified as 0-20 cm (Loam), 20-40 cm (Sandy loam), and 40-100 cm (Loam). The dominant plant species in the natural steppe were Stipa krylovii Roshev, Cleistogenes squarrosa, Artemisia frigida, and Leymus chinensis. The land use in the study area is for grazing and farming. The grassland in this area suffers from shrub encroachment by C. microphylla in many places, resulting in a landscape characterized by a mosaic of shrub and grass patches. C. microphylla (Figure 1a,b) has compound leaves and spines in the stem and widely distributes over gentle hillslopes or in places disturbed by overgrazing or strong anthropogenic activity. The experimental plot was 100\% covered with shrubs and grasses. The landscape of the study site in the early growing season was shown in Figure $1 \mathrm{~b}$ with an earlier flowering period of harvesting shrub (HS) than natural shrub (NS). In addition, the harvested and regrown shrub was obviously shorter than the natural, unharvested shrub (Figure 1c). The grazing pressure here increased from 0.91 sheep per hectare in 1950 to approximately 2.68 sheep per hectare in 2013 [36].
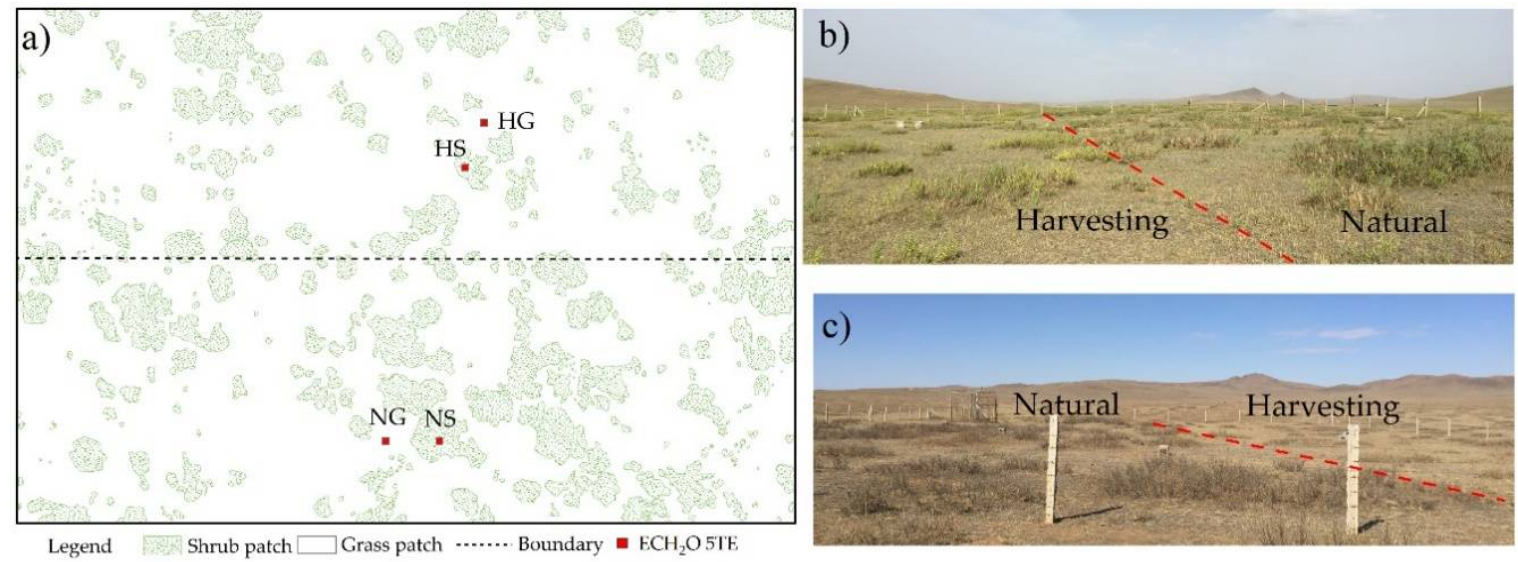

Figure 1. (a) The shrub patch distribution patterns and the locations of the $\mathrm{ECH}_{2} \mathrm{O}$ 5TE sensors in harvesting and natural parts, NG: natural grass, NS: natural shrub, HG: harvesting grass, HS: harvesting shrub; (b) the landscape of the study site in the growing season; (c) the landscape of the study site before the growing season.

\subsection{Observation of Soil Water Dynamics}

The experimental plot $(44 \mathrm{~m} \times 68 \mathrm{~m})$ of harvested plants versus not harvested were established in the shrub encroached grassland of Inner Mongolia Plateau of China. In August 2014, we built a fence to protect this flat and open area and established an automatic meteorological station there. We divided this plot into two parts. A large harvester machine was used in one part (Figure 1, $22 \mathrm{~m} \times 68 \mathrm{~m}$ ) to remove the aboveground biomass of grass and shrub together on September 2013, leaving the belowground portions of plants intact. The other part $(22 \mathrm{~m} \times 68 \mathrm{~m})$ was kept in its original state. Four continuous soil moisture observation sites were established to monitor soil moisture under natural grass (NG), NS, harvesting grass (HG), and HS with one replicate for each treatment. However, one-year's continuous monitoring was applied to verify the difference in soil moisture among the sites. The paired sample T-test was performed to compare group means in this study with SPSS 24.0 (IBM Corporation, Armonk, New York, United States, 2016) for soil moisture at different depths.

We totally installed twenty $\mathrm{ECH}_{2} \mathrm{O}$ 5TE sensors (Decagon Devices, Pullman, WA, USA) to measure the volume water content (VWC) $\left(\mathrm{cm}^{3} \mathrm{~cm}^{-3}\right)$ in September 2014. To eliminate the influence 
of disturbance of the installation of instruments, we collected soil moisture data from June 2015 to May 2016 to analyze the dynamics of soil water due to harvesting treatments. The $\mathrm{ECH}_{2} \mathrm{O}$ sensors can provide accurate, precise, and continuous measurements [37]. The 5TE probes determine VWC using capacitance to measure the apparent dielectric constant of the surrounding medium with a frequency of $70 \mathrm{MHz}$. The accuracy of the sensors amounted to \pm 0.012 for moisture measurement. Moreover, all the 5TE sensors were compared with each other before installation. Errors associated with the sensor-to-sensor variability were less than $2 \%$. Two soil profiles were installed at each site, one of them beneath the standard C. microphylla canopy, and the other one in the interspace grass, approximately $2 \mathrm{~m}$ away from shrub canopy (Figure 1a). Five $\mathrm{ECH}_{2} \mathrm{O}$ 5TE sensors were used for each soil profile at the depths of $5 \mathrm{~cm}, 15 \mathrm{~cm}, 30 \mathrm{~cm}, 50 \mathrm{~cm}$, and $80 \mathrm{~cm}$ to represent soil moistures of $0-10 \mathrm{~cm}$, $10-20 \mathrm{~cm}, 20-40 \mathrm{~cm}, 40-60 \mathrm{~cm}$, and $60-100 \mathrm{~cm}$ with time intervals of $10 \mathrm{~min}$. The temporal contour map of VWC from January 2015 to May 2016 used the daily average VWC and was processed in Surfer 15.0 (Golden Software Inc., Golden, CO, USA, 2017). Soil water storage (WS, $\mathrm{mm}$ ) was calculated by VWC multiplying the corresponding soil thickness.

\subsection{Shrub Pattern Analysis and Vegetation Investigation}

In the harvesting and the control plots, three $5 \mathrm{~m} \times 5 \mathrm{~m}$ quadrats for shrub patches and three $1 \mathrm{~m} \times 1 \mathrm{~m}$ quadrats for interspace grass patches were established to analyze the patch configuration, biomass, and herb community. We pursued the plot investigation as below. First, we measured the crown diameters, height, and biomass of all shrub patches in three shrub quadrats. Second, we recorded species names and measured the mean cover, height, and biomass of each species in three $1 \mathrm{~m}^{2}$ herb quadrats. In detail, the aboveground biomass of shrub (AGB-s) and grass (AGB-g) were sampled by clipping live vegetation rooted within the quadrat to the ground surface. The biomass was determined by oven-drying at $65^{\circ} \mathrm{C}$ to a constant weight. The average height and diameter of C. microphylla were assessed by measuring the three typical shrubs of each site six times in August 2016. The edges of the shrub patches in the field were visually identified based on the projective geometry of the crown shape and size of shrubs growing in isolation or in dense clusters. We divided the plot to $1 \mathrm{~m} \times 1 \mathrm{~m}$ cells using ropes. The location and spatial patterns of shrub patches in each cell were recorded one by one on coordinate paper in the field and then digitized using ArcGIS 10 (ESRI Inc., Redlands, CA, USA, 2011); shrub coverage, size, and the spatial distribution of shrub patches were estimated using Fragstats 4 [38]. Shrub density refers to the number of shrubs within a unit area, whereas shrub cover refers to the ratio of the whole horizontal projection area of aboveground parts to the quadrat area. According to the guidebook of Fragstats [38], the largest patch index (LPI) quantifies the percentage of the total landscape area comprised by the largest patch. Euclidean nearest neighbor index (ENN) is the simplest measure of patch context and to quantify patch isolation. Landscape shape index (LSI) provides a standardized measure of the total edge or edge density that adjusts for the size of the landscape. Patch cohesion index (COHESION) measures the physical connectedness of the corresponding patch type. Landscape division index (DIVISION) is based on the cumulative patch area distribution and is interpreted as the probability that two randomly chosen pixels in the landscape are not situated in the same patch. Splitting index (SPLIT) increases as the landscape is increasingly subdivided into smaller patches. Aggregation index (AI) shows the frequency with which different pairs of patch types appear side-by-side on the map. These indices are calculated by the following equations:

$$
\begin{aligned}
& \mathrm{LPI}= \frac{\max \left(a_{i j}\right)}{A} \times 100 \\
& \mathrm{ENN}=h_{i j} \\
& \mathrm{LSI}=\frac{0.25 \times \sum_{k=1}^{m} e_{i k}^{*}}{\sqrt{A}}
\end{aligned}
$$




$$
\begin{gathered}
\text { COHESION }=\left[1-\frac{\sum_{j=1}^{n} p_{i j}^{*}}{\sum_{j=1}^{n} p_{i j}^{*} \sqrt{a_{i j}^{*}}}\right] \cdot\left[1-\frac{1}{\sqrt{Z}}\right]^{-1} \times 100 \\
\text { DIVISION }=\left[1-\sum_{j=1}^{n}\left(\frac{a_{i j}}{A}\right)^{2}\right] \\
\text { SPLIT }=\frac{A^{2}}{\sum_{j=1}^{n} a_{i j}^{2}} \\
\mathrm{AI}=\left[\sum_{i=1}^{m}\left(\frac{g_{i i}}{\max \rightarrow g_{i i}}\right) P_{i}\right] \times 100
\end{gathered}
$$

where, $a_{i j}$ is the area $\left(\mathrm{m}^{2}\right)$ of patch $i j ; A$ is total landscape area $\left(\mathrm{m}^{2}\right) ; h_{i j}$ is the distance $(m)$ from patch ij to the nearest neighboring patch of the same type, based on the shortest edge-to-edge distance, computed from cell center to cell center; $e_{i k}^{*}$ is the total length $(m)$ of the edge in the landscape between patch types $i$ and $\mathrm{k} ; p_{i j}^{*}$ is the perimeter of patch $i j$ in terms of the number of cell surfaces; $a_{i j}^{*}$ is the area of patch $i j$ in terms of the number of cells; $Z$ is the total number of cells in the landscape; $g_{i i}$ is the number of like adjacencies (joins) between pixels of patch type (class) $i$ based on the single-count method; $\max \rightarrow g_{i i}$ is the maximum of $g_{i i} ; P_{i}$ is the proportion of landscape comprised of patch type (class) $i$.

\subsection{Plants Phenology Observation and Physiological Experiments}

Phenology: we separately observed shrub and grass phenology under NG, NS, HG, HS, NSG (grass growing in natural shrub patch), and HSG (grass growing in harvesting shrub patch) for three growing seasons from 2015 to 2017. The growing season usually begins in April and ends in October. Generally, we observed every other day in spring and every three days in autumn. We selected 5 to 10 representative shrubs with marks and 40 herbs in each stage. The sample sites arrive at a certain phenology when more than half of these individuals show the characteristics of this phenology. We ignored grassland flowering phenology due to various species. The observation criteria and methods referred to the observation methods of phenology in China [39].

Water use sources $\left(\delta^{2} \mathrm{H}\right.$ and $\left.\delta^{18} \mathrm{O}\right)$ : the isotope ratios in plants could be regarded as a mixture of that in several sources. The proportional contribution of these several sources to a mixture could be quantitatively determined by stable isotope mixing models. This model assumes that the source signatures closest to that of the mixture provide the greatest contribution [40]. Plants in water-limited areas mainly utilize soil moisture. Therefore, plant and soil samples for determination of isotope ratios were collected monthly at each site from May to October 2016. Soil samples were collected at 8 layers $(0-5,5-10,10-20,20-30,30-40,40-60,60-80,80-100 \mathrm{~cm})$ using a $5 \mathrm{~cm}$ diameter hand bucket auger. There were three soil cores randomly drilled within the experimental plot at each sampling time. Concurrent with the soil sampling, non-photosynthetic and lignified twig sections were collected from 3 to 5 individual shrubs and grasses growing near the soil sampling cores at midday to ensure the establishment of isotopic steady-state conditions. Plant and soil samples were immediately put into $15 \mathrm{~mL}$ screw-cap glass vials and placed in a portable cooler for transporting back to the laboratory. Plant tissue and soil water samples were extracted with a cryogenic vacuum distillation system [41]. The isotopic composition of all of the liquid samples was analyzed by an Isotopic Ratio Infrared Spectroscopy (IRIS) system (Model DLT-100; Los Gatos Research, Mountain View, CA, USA) at the State Key Laboratory of Earth Surface Process and Resource Ecology, Beijing Normal University. The IsoSource program was applied to determine the fractional contribution of diverse water sources to plants [42]. The source increment was defined as $1 \%$ and mass balance tolerance was set at 0.1 .

Water use efficiency $\left(\delta^{13} \mathrm{C}\right)$ : the water use efficiency is typically defined as the ratio of biomass produced to the rate of transpiration. It is positively correlated with the foliage $\delta^{13} \mathrm{C}$ value in the 
long-term [43]. Foliage samples for stable carbon-isotope analysis were only collected during the growing season (May to September) of 2016. Samples were collected from 4 to 6 individuals of C. microphylla. The foliage was rinsed, dried to a constant weight at $70{ }^{\circ} \mathrm{C}$ for $48 \mathrm{~h}$, ground to 40 mesh, and then subsampled. A total of 0.650 to $0.750 \mathrm{mg}$ of Sample were put in a tin capsule and placed in the sample plate with individual cells orderly. Foliage samples were combusted and analyzed using a stable isotope analyzer with a part-per-billion level precision (Model G2201-I; Picarro Inc., Santa Clara, CA, USA).

\section{Results}

\subsection{Landscape Patterns and Plant Characteristics Change after Harvesting}

After three years after harvesting, the shrub cover of the cleared half part was $60 \%$ of the natural part in 2016 (Table 1). The shrub biomass of HS was still only 25\% of the NS. According to the grass biomass and the cover of interspace grass patches, the grass had already recovered to the original state. The patch size of the removal part was about $40 \%$ smaller than the natural part, but they showed same patch density. Besides coverage, the removal shrub was $0.32 \mathrm{~m}$ shorter in average. Even though the harvesting part had a higher LPI, the largest patches of the two sites were similar due to a lower shrub cover of the harvesting part. ENN indicated the shrub patches were closer to the adjacent patches in the natural part than the harvesting part. In addition, the LSI and SPLIT both showed that natural shrubs were more dispersive among the patches than harvesting shrubs which we could also see from Figure 1. COHESION, DIVISION, and AI were close between the two groups. In brief, C. microphylla in the natural part was higher with a larger shrub cover and patch size, while distributed closer and more dispersive than the harvesting part.

Table 1. The comparison of landscape indices between natural and harvesting shrub encroached grassland.

\begin{tabular}{|c|c|c|c|c|c|c|c|}
\hline Sites & $\begin{array}{l}\text { Shrub } \\
\text { Cover }\end{array}$ & $\begin{array}{l}\text { Interspace } \\
\text { Grass Cover }\end{array}$ & $\begin{array}{l}\text { Shrub } \\
\text { Biomass }\end{array}$ & $\begin{array}{c}\text { Interspace } \\
\text { Grass Biomass }\end{array}$ & Patch Size & HEIGHT & $\begin{array}{c}\text { Patch } \\
\text { Density }\end{array}$ \\
\hline $\begin{array}{l}\text { Natural } \\
\text { shrub }\end{array}$ & $24.37 \%$ & $76.0 \%$ & $496.8 \mathrm{~g} / \mathrm{m}^{2}$ & $72.5 \mathrm{~g} / \mathrm{m}^{2}$ & $1.72 \mathrm{~m}^{2}$ & $0.71 \mathrm{~m}$ & $0.14 \mathrm{~m}^{-2}$ \\
\hline \multirow[t]{2}{*}{$\begin{array}{l}\text { Harvesting } \\
\text { shrub }\end{array}$} & $14.58 \%$ & $79.3 \%$ & $123.4 \mathrm{~g} / \mathrm{m}^{2}$ & $82.0 \mathrm{~g} / \mathrm{m}^{2}$ & $1.06 \mathrm{~m}^{2}$ & $0.39 \mathrm{~m}$ & $0.14 \mathrm{~m}^{-2}$ \\
\hline & LPI & ENN & LSI & COHESION & DIVISION & SPLIT & AI \\
\hline $\begin{array}{l}\text { Natural } \\
\text { shrub }\end{array}$ & $5.53 \%$ & 0.46 & 16.79 & $95.53 \%$ & $97.87 \%$ & $46.91 \%$ & $92.11 \%$ \\
\hline $\begin{array}{l}\text { Harvesting } \\
\text { shrub }\end{array}$ & $10.13 \%$ & 0.51 & 14.21 & $95.49 \%$ & $96.94 \%$ & $32.73 \%$ & $92.60 \%$ \\
\hline
\end{tabular}

LPI: largest patch index; ENN: Euclidean nearest neighbor index; LSI: landscape shape index; COHESION: patch cohesion index; DIVISION: landscape division index; SPLIT: splitting index; AI: aggregation index.

\subsection{Annual Dynamics of Soil VWC in Four Sites}

Figure 2 provided the variation of VWC across a year by temporal interpolation. Firstly, the soil moisture was highest in autumn and spring, but lower in summer and winter in all sites. Secondly, the soil moisture increased after harvesting activity (HG and HS) accompanied by higher seasonal fluctuations. The difference between grass patches was higher than shrub ones. In April, spring rainfall and snowmelt brought a deeper wetting front in HG and HS (about $60 \mathrm{~cm}$ ) than the natural parts (about $30 \mathrm{~cm}$ ), which kept longer than about 30 days in the harvesting part than the natural part. In the comparison between shrub and grass, soil moisture beneath shrubs showed a larger fluctuation across a year with a higher VWC in the deep layers $(60-100 \mathrm{~cm})$, whereas the VWC of the deep layer under grass remained stable. 

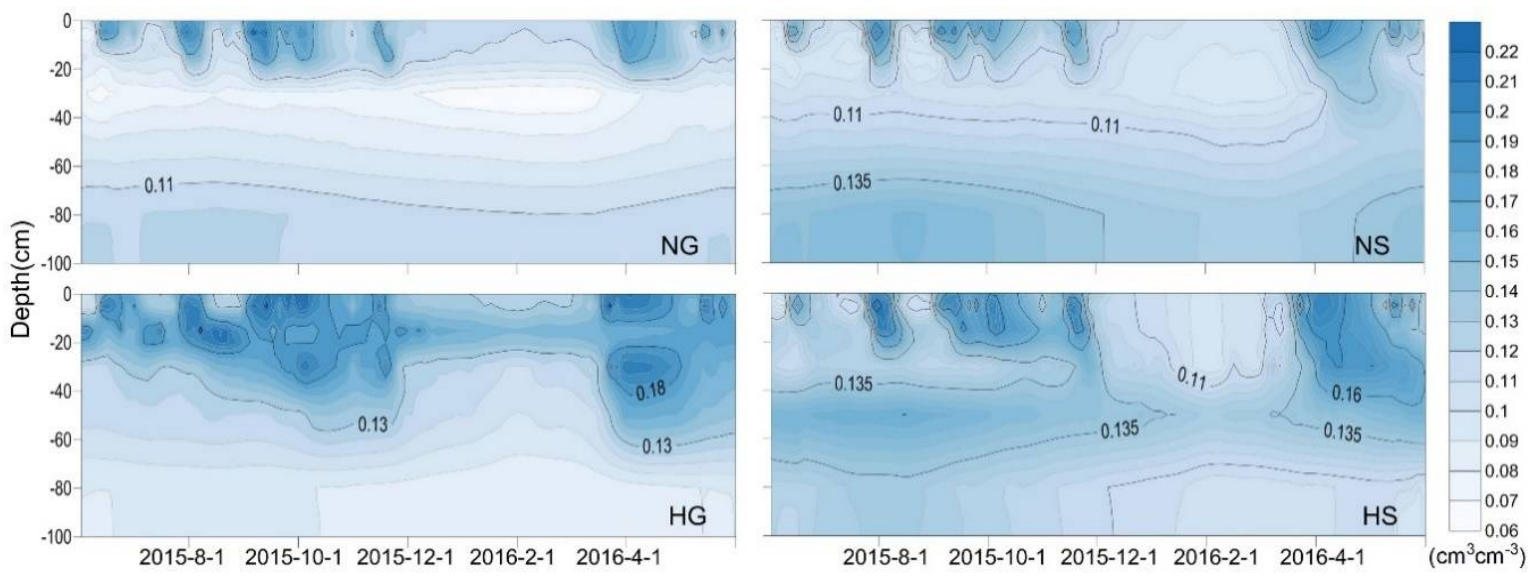

Figure 2. The volume water content (VWC) $\left(\mathrm{cm}^{3} \mathrm{~cm}^{-3}\right)$ dynamics by temporal interpolation across a year (June 2015 to May 2016).

The paired sample T-test (Table 2) was applied to quantitatively analyze the difference of soil water status among four sites. VWC in HG was significantly higher than NG except for the deepest layer, especially in 20-40 cm which was about 2-fold of NG. Soil moisture beneath shrubs showed the same trend in all layers after harvesting (Table 2, HS-NS). In addition, VWC showed a larger variance between grass sites (HG-NG) than shrub sites (HS-NS), indicating that the removal displayed a stronger effect of soil water recovery beneath grass patches. In the comparison of soil moisture between shrub and grass, NS was lower than NG in the shallow layer $(0-20 \mathrm{~cm})$, while higher in other layers $(20-100 \mathrm{~cm})$. After harvesting, the VWC of HS and HG still followed the above trends except for $20-40 \mathrm{~cm}$ that HG was 0.018 higher than HS. According to these changes, harvesting seemed to benefit the soil water recovery, especially under grass patches.

Table 2. The paired sample T-test of monthly average VWC.

\begin{tabular}{cccccc}
\hline Paired Sites & $\mathbf{0 - 1 0} \mathbf{~ c m}$ & $\mathbf{1 0 - 2 0} \mathbf{~ c m}$ & $\mathbf{2 0 - 4 0 ~} \mathbf{~ m}$ & $\mathbf{4 0 - 6 0} \mathbf{~ c m}$ & $\mathbf{6 0 - 1 0 0 ~} \mathbf{~ m}$ \\
\hline HG-NG & $0.026^{* *}$ & $0.051^{* *}$ & $0.076^{* *}$ & $0.035^{* *}$ & $-0.028^{* *}$ \\
HS-NS & $0.011^{* *}$ & $0.031^{* *}$ & $0.026^{* *}$ & $0.030^{* *}$ & $-0.025^{* *}$ \\
NG-NS & $0.006^{* *}$ & $0.012^{* *}$ & $-0.031^{* *}$ & $-0.027^{* *}$ & $-0.023^{* *}$ \\
HG-HS & $0.021^{* *}$ & $0.032^{* *}$ & $0.018^{*}$ & $-0.021^{* *}$ & $-0.026^{* *}$ \\
\hline${ }^{*}$ significant at $p=0.05$ confidence level; ** significant at $p=0.01$ confidence level.
\end{tabular}

The WS of four sites across a year are shown in Figure 3. Generally, WS followed the same trends of VWC. NG and NS had lower WS of monthly averages as $104.6 \pm 6.4 \mathrm{~mm}$ and $123.7 \pm 7.7 \mathrm{~mm}$, which also did not vary much across the year. In contrast, HG and HS owned a higher storage of about $123.5 \pm 12.7 \mathrm{~mm}$ and $129.2 \pm 11.9 \mathrm{~mm}$, showing a stronger seasonal fluctuation than the natural part. In addition, the WS of the four sites was characterized in a vertical distribution. The 0-20 cm layer of NG owned the largest proportion (25\%), while the lowest was in $20-40 \mathrm{~cm}(14 \%)$, followed by an increasing WS in deeper layers $(17 \%, 22 \%$, and $22 \%)$. NS possessed an $18 \%$ higher storage than NG in total, while the structure of water storage $(20 \%, 17 \%, 19 \%, 22 \%$, and $22 \%$ at soil depths of $-20 \mathrm{~cm}$, 2-40 cm, 4-60 cm, 6-80 cm, 8-100 cm, separately) was similar to NG. Two years after harvesting, WS of grass patch increased by $18 \%$. Moreover, the distribution of WS in HG changed a lot $(27 \%, 24 \%, 20 \%$, $14 \%$, and $14 \%$ at the above 5 layers from $0-100 \mathrm{~cm}$, separately). Water transferred from deep $(6-100 \mathrm{~cm})$ to upper layers $(-40 \mathrm{~cm})$ which occupied $52 \%$ of total water storage. HS possessed the highest WS of four sites with the similar vertical distribution of $\mathrm{HG}(22 \%, 20 \%, 23 \%, 18 \%$, and $18 \%$ at the above 5 layers from $-100 \mathrm{~cm}$, separately). We can conclude that harvesting promoted water recovery in both shrub and grass patches, especially in later ones which narrowed the gap of WS between shrub and 
grass patches. Moreover, harvesting changed the WS distribution mode in which water moved from the deep to upper layers.
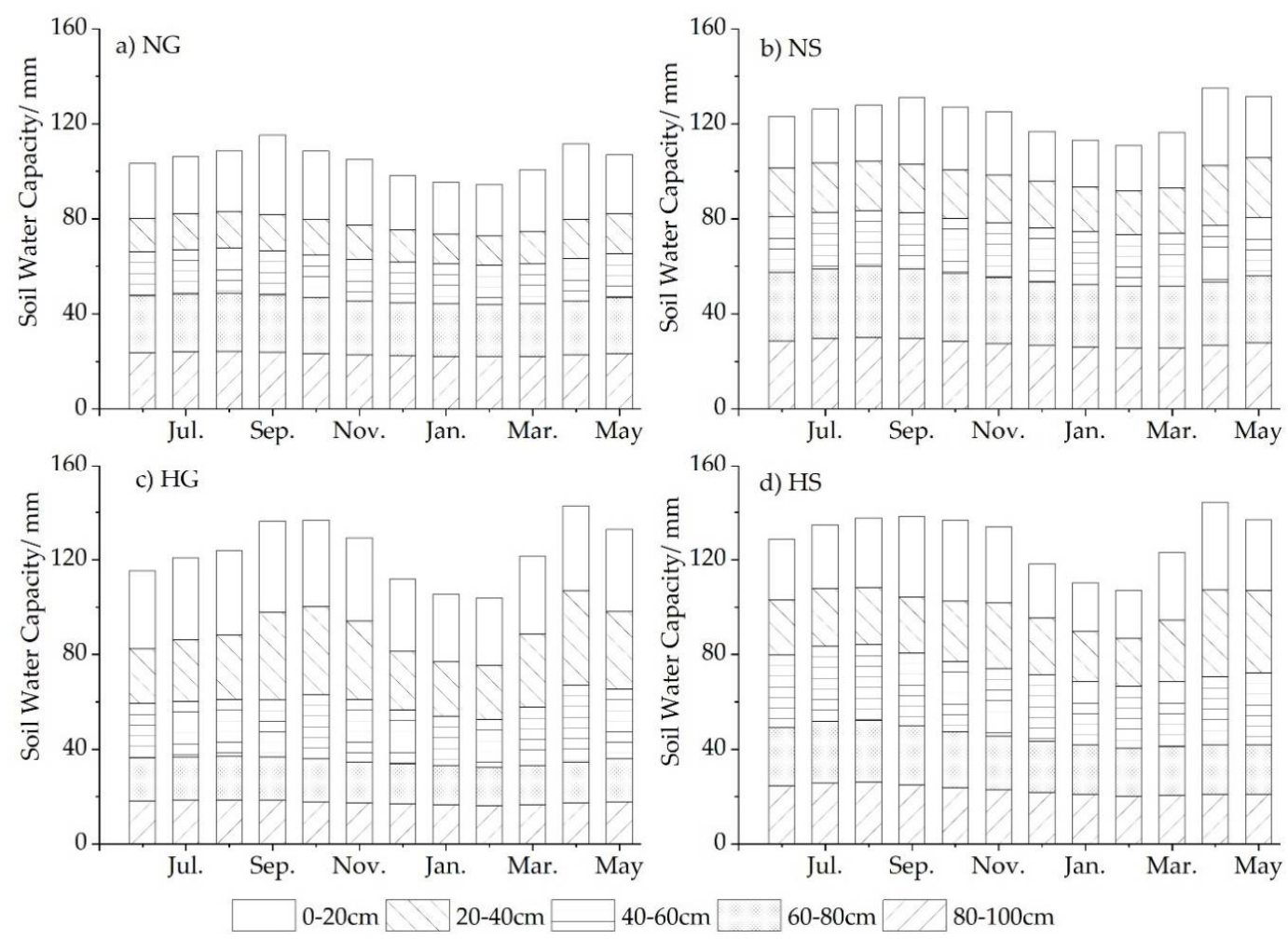

Figure 3. The monthly dynamics of soil water storage in four sites from June 2015 to May 2016. (a)soil water capacity under natural grass (NG) patch; (b) soil water capacity under natural shrub (NS) patch; (c) soil water capacity under harvesting grass (HG) patch; (d) soil water capacity under harvesting shrub (HS) patch.

\subsection{Impacts of Rainfall and Snowmelt Replenishment on Soil Moisture}

Six rainfall events were separately chosen from summer, autumn, and spring to observe soil water dynamics after different rainfall intensities and durations. Soil moisture of 0-10 cm was analyzed here to compare the divergent rainfall replenishment due to its largest responses of all soil layers. This surface layer was also influenced greatest by harvesting activity (for example soil compaction), and its water dynamics could affect that of all the deeper layers. On the 27th of July (Figure 4a), VWC responded rapidly with sharp increases of $0.087,0.045,0.042$, and $0.032 \mathrm{~cm}^{3} \mathrm{~cm}^{-3}$ separately in NS, NG, HS, and HG to $16 \mathrm{~mm}$ rainfall with a strong intensity of $32 \mathrm{~mm} / \mathrm{h}$. On the 4 th of August (Figure 4b), VWC of NS and NG still had a higher increment. In autumn, the rainfall events had a weaker intensity of about $2.1 \mathrm{~mm} / \mathrm{h}$ (Figure $4 \mathrm{c}, \mathrm{d}$ ), VWC increased to $0.079,0.075,0.072$ and $0.060 \mathrm{~cm}^{3} \mathrm{~cm}^{-3}$ separately for NG, HS, NS, and HG, respectively. In spring, the rainfall intensity was the weakest at $0.51 \mathrm{~mm} / \mathrm{h}$ and could last as long as 2 days. In response to $7.8 \mathrm{~mm}$ rainfall (Figure 4e), VWC increased by 0.100 , $0.094,0.072$, and $0.070 \mathrm{~cm}^{3} \mathrm{~cm}^{-3}$ separately in NG, HS, NS, HG, which was the largest increment of rainfalls. The rank was kept after the next rainfalls of $5 \mathrm{~mm}$ and $10.8 \mathrm{~mm}$. Generally, VWC under NS and NG showed a stronger enhancement to strong rainfall intensity in summer while NG and HS gained a higher response to weak rainfall intensity in autumn and spring.

Even though HG exhibited the highest water recovery (Figure 2), the VWC of HG responded the least to all rainfalls (Figure 4). This paradox indicates that there are other factors contributing to water recovery. Winter snowfalls occupy $50 \%$ of the annual precipitation here. Spring snowmelt which replenishes soil all at once may also influence moisture recovery. Snow began to melt one week earlier 
for HS and HG than for NS and NG (Figure $5 \mathrm{a}, \mathrm{b}$ ). The surface layer fluctuated greatest of all layers. At the depth of $0-10 \mathrm{~cm}$, the VWC increased by 0.166 and $0.143 \mathrm{~cm}^{3} \mathrm{~cm}^{-3}$ in HG and HS, while NG and NS were about $0.130 \mathrm{~cm}^{3} \mathrm{~cm}^{-3}$. The large daily fluctuation is due to the freezing and thawing of soil water which is caused by the large diurnal temperature difference. At 10-20 cm, the VWC increments were sorted as HG, HS, NG, and NS, ranging from 0.112 to $0.071 \mathrm{~cm}^{3} \mathrm{~cm}^{-3}$. $\mathrm{HS}\left(0.075 \mathrm{~cm}^{3} \mathrm{~cm}^{-3}\right)$ started to exceed HG $\left(0.062 \mathrm{~cm}^{3} \mathrm{~cm}^{-3}\right)$ from 20 to $40 \mathrm{~cm}$, NS and NG were still behind them as 0.043 and $0.021 \mathrm{~cm}^{3} \mathrm{~cm}^{-3}$. The VWC increment after snowmelt ranged from 0.009 to $0.021 \mathrm{~cm}^{3} \mathrm{~cm}^{-3}$ at depths of 40-60 cm, sorted by HS, HG, NS, and NG. No significant changes were found at the deepest layer $(60-100 \mathrm{~cm})$. Therefore, the higher snowmelt replenishment may contribute to the water recovery of harvesting soil, especially under HG.
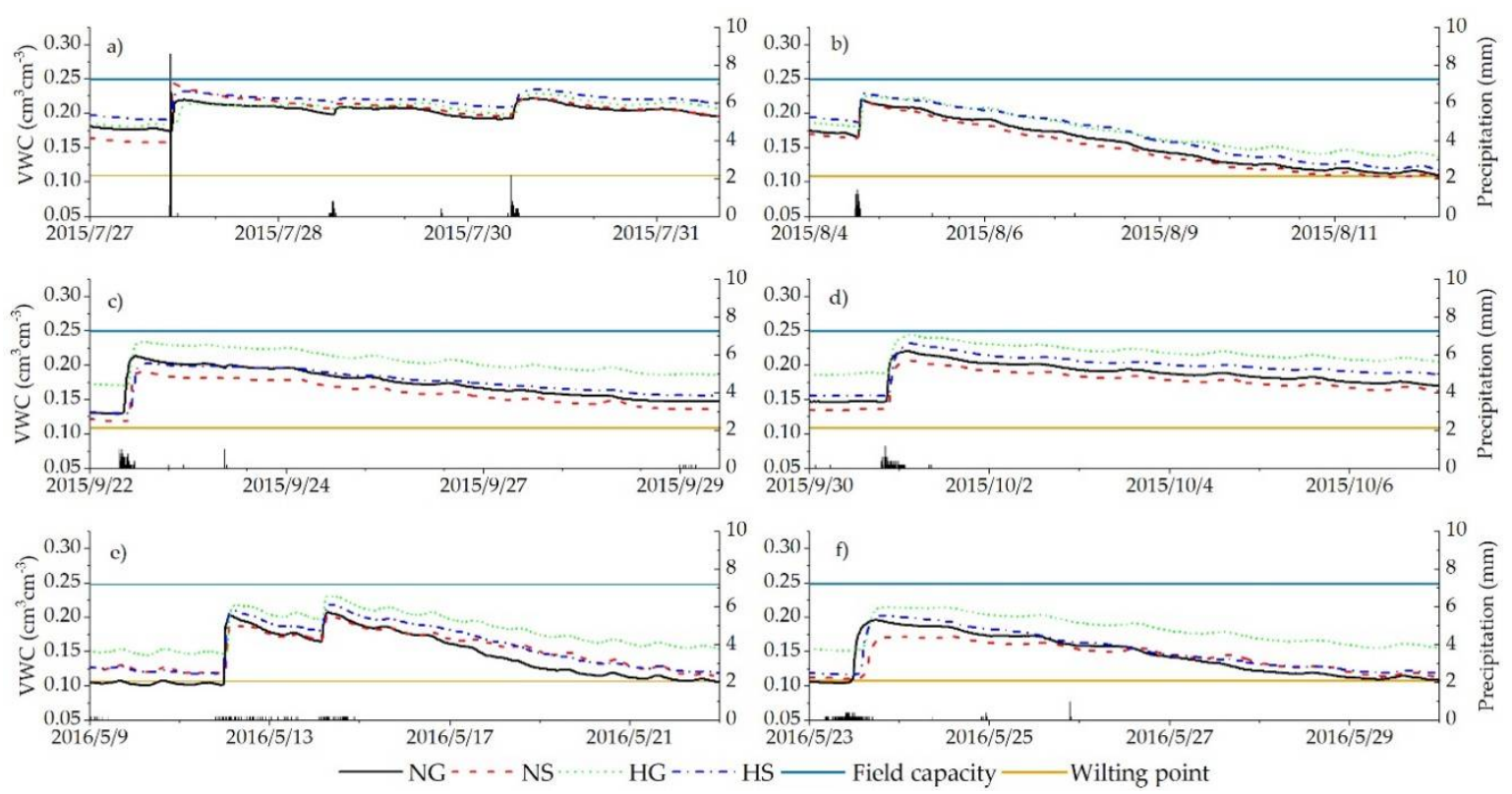

Figure 4. The variation of soil volumetric water content (VWC) at soil depths of 0-10 cm after rainfalls. (a) $16 \mathrm{~mm}, 2.6 \mathrm{~mm}, 6.3 \mathrm{~mm}$; (b) $9 \mathrm{~mm}$; (c) $12 \mathrm{~mm}$; (d) $11.2 \mathrm{~mm}$; (e) $7.8 \mathrm{~mm}, 5 \mathrm{~mm}$; (f) $10.8 \mathrm{~mm}$. The field capacity and wilting point refer to Yu et al. [44].
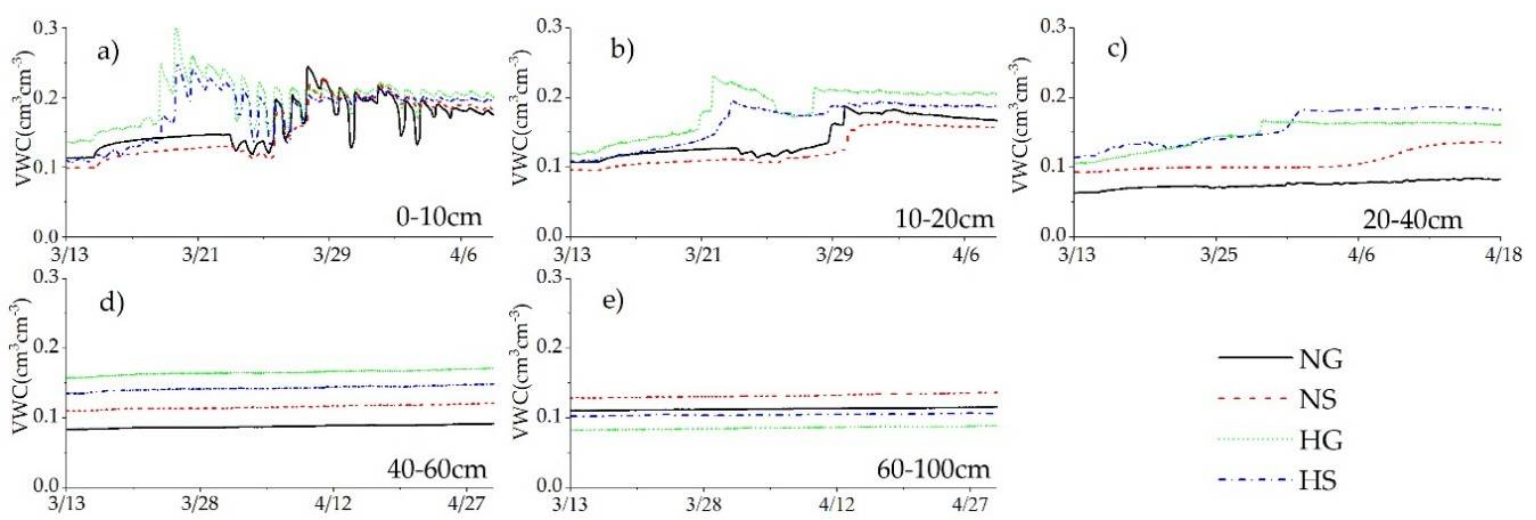

Figure 5. The VWC variance in early spring (2016) for all sites from 0-100 cm. (a) VWC dynamics at 0-10 cm; (b) VWC dynamics at 10-20 cm; (c) VWC dynamics at 20-40 cm; (d) VWC dynamics at 40-60 cm; (e) VWC dynamics at 60-100 cm. 


\subsection{Impacts of Harvesting on Phenology and WUE}

Phenology periods of shrub and grass were observed in the growing season from 2015 to 2017 (Figure 6). For shrubs, the results showed that HS had significant earlier phenologies by about 2.3 to $4.3 \mathrm{~d}$ than NS $(p<0.05)$, whereas the growing season length of HS was shorter than NS by about $1.3 \mathrm{~d}(p=0.057)$. For grasses in shrub patches, harvesting activity also significantly advanced their phenologies about $1-2 \mathrm{~d}(0.9 \mathrm{~d}$ on average $)$ in spring and $7.3 \mathrm{~d}$ in autumn $(p<0.05)$. At the same time, the growing season length was also shortened by $6.7 \mathrm{~d}$ in HSG at a significant level $(p=0.07)$. For interspace grasses, HG showed earlier phenological periods about $1.2 \mathrm{~d}(p<0.05)$ than NG in spring. HG was earlier than NG by about $5 \mathrm{~d}$ of withering from 2015 to 2016, but later by $2 \mathrm{~d}$ in 2017. HG was also shorter by $4 \mathrm{~d}$ in growing season length than NG $(p<0.05)$. To sum up, harvesting operations obviously advanced the phenology of both shrub and grass and shortened the growing season length.

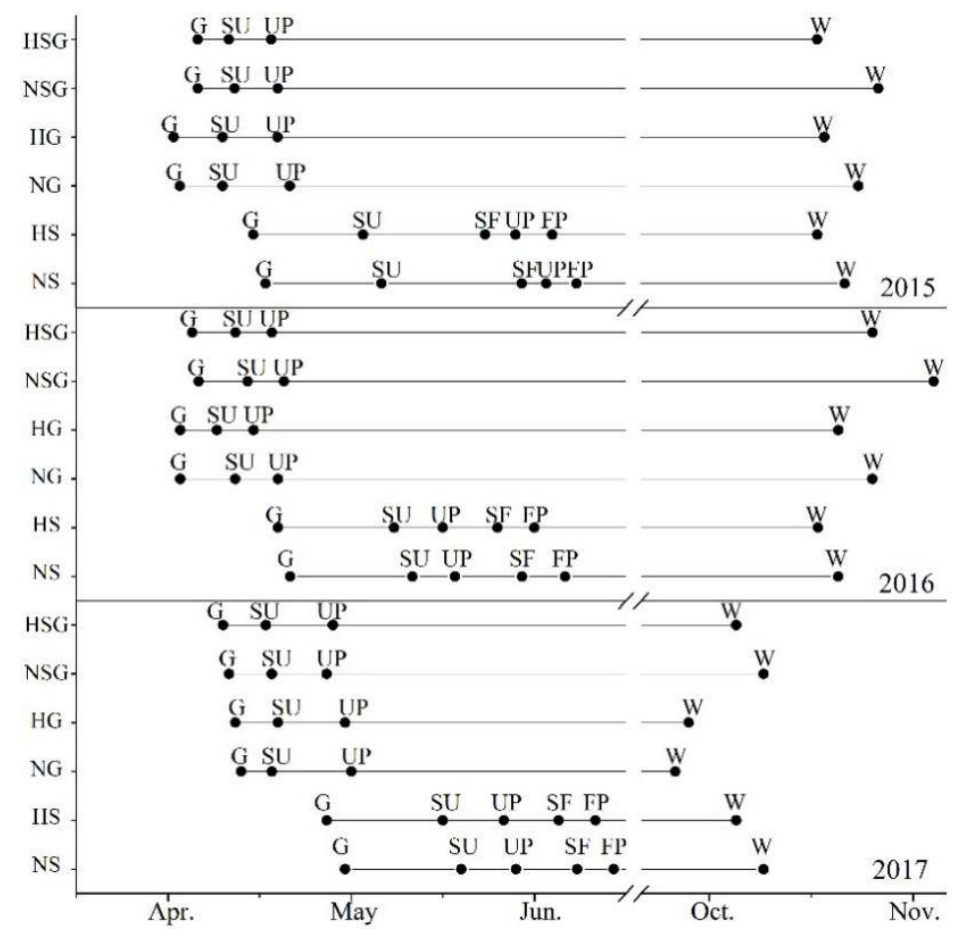

Figure 6. The phenologies of shrub and grass from 2015 to 2017. G: germination; SU: start of unfolding; UP: unfolding peak; SF: start of flowering; FP: flowering peak; W, withering. HSG: grass in harvesting shrub patch; NSG: grass in natural shrub patch.

Furthermore, water use efficiency and the water source of shrubs were compared in Figure 7. Foliage $\delta^{13} \mathrm{C}$ is positively related to WUE. The result demonstrated that WUE gradually decreased across the growing season and harvesting activity triggered a higher WUE (Figure 7a,b). The average $\delta^{13} \mathrm{C}$ of NS and HS were separate as $-26.49 \pm 1.01 \%$ and $-25.56 \pm 0.73 \%$, increasing about $1 \%$. The fraction of water uptake showed that HS generally owned a shallower water source than NS (Figure $7 \mathrm{c})$, which means shallow layers $(0-40 \mathrm{~cm})$ could support shrub growth in the larger proportion of HS $(71.6 \%)$, though smaller in NS (40.3\%) on average, especially in July and August. Besides, the water uptake of HS showed more plasticity to various layers while NG absorbed more water from the deep layer across the growing season. 

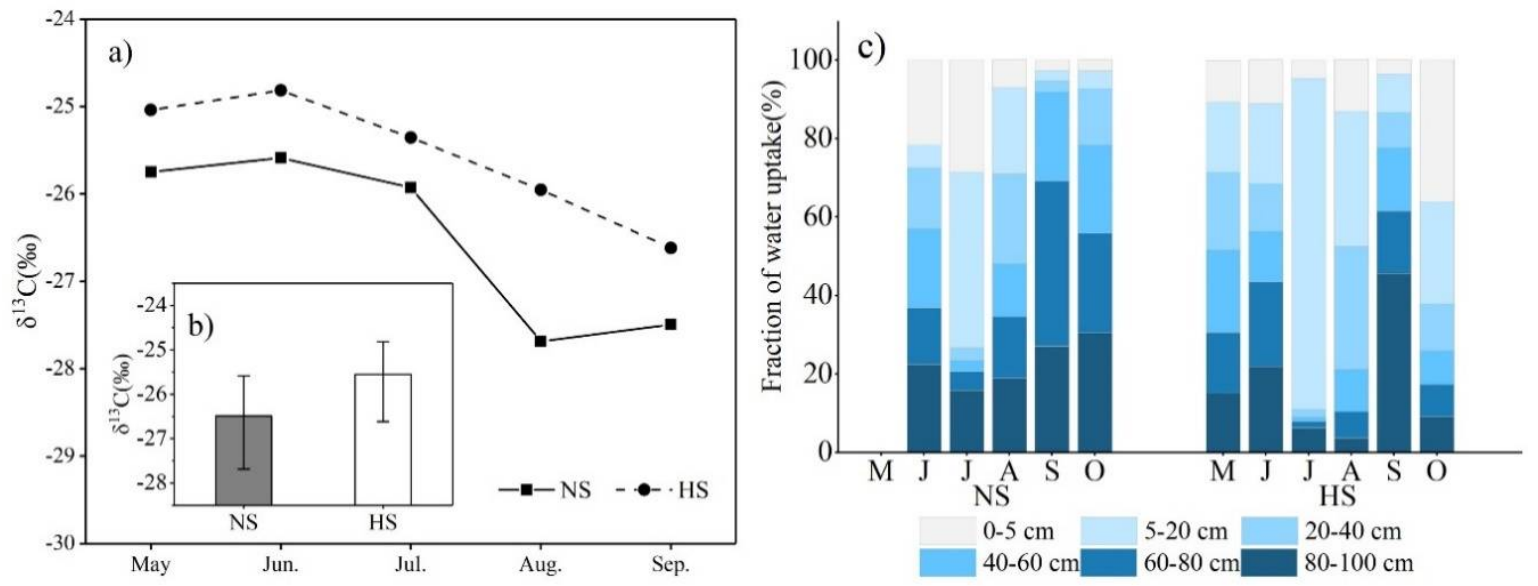

Figure 7. (a) Shrub water use efficiency (reflected by foliage $\delta^{13} \mathrm{C}$ ) in NS and HS across the growing season; (b) average $\delta^{13} \mathrm{C}$ of two groups from May to September; (c) shrub water uptake fraction of 0-100 cm soil water.

\section{Discussion}

Harvesting activity promoted water recovery, especially under grass patches. After harvesting, the moisture condition between shrub and grass patches became closer and more aggregated on shallow layers. Furthermore, we summarized the causes and mechanisms of this phenomenon by discussing hydrological processes and plant physiological responses to harvesting.

\subsection{Effect of Precipitation on Soil Moisture}

\subsubsection{Rainfall}

Soil moisture was obviously enhanced after harvesting activity. Generally, the soil under NG and NS showed higher fluctuations to rainfall events (Figure 4). This may be caused by a lower infiltration in harvesting surface ground after rainfalls. Previous studies revealed that a decreased infiltration rate was caused by trampling in grazing activities [45]. The harvesting machine we used here was like trampling, compacting the soil while harvesting plants, especially on the surface layer. Therefore, it is reasonable that the infiltration rate here decreased after harvesting. Besides, it is contradictory that rainfall always triggered the lowest response on HG where water recovery was the highest of all sites (Figure 4). These results indicated that the other reason might benefit on soil water recovery after grassland harvesting.

\subsubsection{Snowfall}

Our study revealed that VWC of HG and HS fluctuated stronger and had a larger moisture supplement in all layers after snowmelt. It is an explanation for soil moisture recovery after harvesting. Our result was consistent with the previous study which proved that winter precipitation could enhance soil water content and storage [46]. However, the stable soil moisture after snowmelt on the depth of 60-100 cm may be caused by the existence of calcic horizon which functioned as a "dam" and has a very low hydraulic conductivity and inhibit further infiltration [36,47].

\subsection{Water Consumption by Plants}

The VWC and WS beneath HG and HS were higher than natural ones, especially between NG and HG with an $18 \%$ gap in total water storage (Figure 3). This was consistent with the study in Colorado, which suggested that soil moisture enhancement by grass removal was much higher than by shrub removal [48]. Besides snowmelt, this might also be caused by a higher water consumption in the natural part. In detail, the difference of VWC between NG and HG became larger and larger 
after the response peak to rainfalls (Figure $4 \mathrm{~b}, \mathrm{e}, \mathrm{f}$ ). Besides infiltrating the deeper layer, the decreased soil VWC of $0-10 \mathrm{~cm}$ might go back to the atmosphere by evapotranspiration. However, we observed that less VWC increments on deeper layers under natural ground, which meant that the soil water of $0-10 \mathrm{~cm}$ was consumed more in NG. There was a sharp drop in aboveground biomass and the coverage of shrub after harvesting. The biomass of HS was just one-quarter that of NS three years after harvesting (Table 1). Lower plant biomass would inevitably result in the reduction of plant transpiration and the total evapotranspiration of this part. In addition, the WUE of shrubs increased after harvesting (Figure 7a,b), which also decreased plant transpiration when producing the same amount of biomass. Therefore, the lower biomass and higher WUE of plants after harvesting combined to reduce evapotranspiration, contributing to water recovery.

\subsection{Plant Physiological Responses}

The growing season length of HS and HG was shorter than NS and NG. Most of the phenology periods were advanced as well. These changes in temporal niches shortened the water uptake time and might reduce the consumption of soil moisture. Besides phenology changes, HS also showed a shallower water use resource. This pattern may be caused by a rich soil moisture (Figure 2), less water consumes following shrub removal (Figure 4) or competition release in shallow water by less HSG biomass after harvesting. Moreover, consistent with the previous study [31], the WUE of shrub also increased after harvesting. These attributes all contributed to more water-saving shrubs after harvesting. Therefore, it was reasonable that soil water recovered after harvesting. Moreover, this effect would last for several years in semiarid environments due to the slow rates of restoration.

\subsection{Predicted Future Scenario and Implications}

Meanwhile, a remarkable shift from light to heavy rain events has been observed and winter precipitation amount/intensity has increased by $7 \%$ in arid and semi-arid regions of Northwest China, and winter is warming up by $0.37^{\circ} \mathrm{C} / 10$ a [49-51]. The soil under the shrub would be expected to gain more available water than the soil under grass. This would interact with regional warming and further reinforce the effects of the microclimate [52]. Therefore, shrub expansion would be enhanced due to the higher rainfall intensity, longer drought interval, increasing winter precipitation amount, and warming [36].

Harvesting activity promoted the recovery of soil moisture and narrowed the WS difference between shrub and grass patches, which might weaken the shrub survival advantages in soil water availability under global warming and rainfall regime chances. The previous study proved that if not properly managed, the manual cleaning of shrubs might lead to higher densities over the long term than before the control because the disturbed soil was ideal for seedlings establishment [53]. However, we did not find the variation of shrub density under removal by the large harvester machine (Table 1). From the perspective of water conservation and control shrub encroachment, harvesting activity in shrub encroached grassland with appropriate frequency would be a good choice for grassland management.

\section{Conclusions}

1. Shrub patches showed a slow regeneration process. After three years' recovery, C. microphylla was still $40 \%$ shorter than natural ones and sparsely distributed with a $60 \%$ of NS in shrub coverage and $25 \%$ of NS in aboveground biomass.

2. Harvesting has seemed to benefit the soil water recovery, especially under grass, impairing the "hydrologic island" effect of shrubs and promoting a balanced distribution of WS between shrub and grass.

3. HS was seemed to be more water-saving than NS due to a higher WUE. The shorter growing season and less biomass in HS, HG, and HSG might reduce the water uptake time and consumption of soil moisture than the natural part. 
4. More snowmelt replenishment, lower water evapotranspiration, shorter growing season, higher WUE, and so forth could jointly contribute to the water recovery of harvesting soil, especially under HG.

Our study provides the first exploration of soil moisture dynamics and difference under harvesting and natural shrub/grass patches and tries to explain this phenomenon from rainfalls, snowmelt, and plant responses. Some of these results could be the basis for further studies and showed application value in shrub encroached grassland management. They also provide fundamental insights into widely understanding soil water dynamics of such valuable and vulnerable ecosystems in the world.

Author Contributions: X.L. and L.L. conceived the idea, designed the experiments and review the paper, Y.F., L.L., J.W., F.S., H.Y. and L.L. performed the field investigation, Y.F. analyzed the results and wrote the paper.

Funding: This research has been funded by the Strategic Priority Research Program of Chinese Academy of Sciences, grant number XDA20100102; the National Natural Science Foundation of China, grant number 91425301; and the PCSIRT, grant number IRT_15R06.

Acknowledgments: The study has also been supported by projects by the state Key Laboratory of Earth Surface Processes and Resource Ecology and by Ten Thousand Talent Program for leading young scientist.

Conflicts of Interest: The authors declare that they have no conflict of interest. This article does not contain any studies with human participants or animals performed by any of the authors.

\section{References}

1. Aldous, A.E. Effect of Different Clipping Treatments on the Yield and Vigor of Prairie Grass Vegetation. Ecology 1930, 11, 752-759. [CrossRef]

2. Armesto, J.J.; Pickett, S.T.A. Experiments on Disturbance in Old-Field Plant Communities: Impact on Species Richness and Abundance. Ecology 1985, 66, 230-240. [CrossRef]

3. Kobayashi, T.; Hori, Y.; Nomoto, N. Effects of trampling and vegetation removal on species diversity and micro-environment under different shade conditions. J. Veg. Sci. 1997, 8, 873-880. [CrossRef]

4. Vestergaard, P. Response to mowing of coastal brackish meadow plant communities along an elevational gradient. Nord. J. Bot. 2008, 14, 569-587. [CrossRef]

5. Zoller, S.H.; Korner, C. Influences of mowing and grazing on plant species composition in calcareous grassland. Bot. Helv. 1998, 108, 57-67.

6. Eldridge, D.J.; Wang, L.; Ruiz-Colmenero, M. Shrub encroachment alters the spatial patterns of infiltration. Ecohydrology 2014. [CrossRef]

7. Cahoon, S.M.P.; Sullivan, P.F.; Post, E. Carbon and water relations of contrasting Arctic plants: Implications for shrub expansion in West Greenland. Ecosphere 2016, 7. [CrossRef]

8. D'Odorico, P.; Okin, G.S.; Bestelmeyer, B.T. A synthetic review of feedbacks and drivers of shrub encroachment in arid grasslands. Ecohydrology 2012, 5, 520-530. [CrossRef]

9. Maccherini, S.; Marignani, M.; Castagnini, P.; van den Brink, P.J. Multivariate analysis of the response of overgrown semi-natural calcareous grasslands to restorative shrub cutting. Basic Appl. Ecol. 2007, 8, 332-342. [CrossRef]

10. Dzwonko, Z.; Loster, S. A functional analysis of vegetation dynamics in abandoned and restored limestone grasslands. J. Veg. Sci. 2007, 18, 203-212. [CrossRef]

11. Papanastasis, V.P.; Platis, P.D.; Dini-Papanastasi, O. Effects of age and frequency of cutting on productivity of Mediterranean deciduous fodder tree and shrub plantations. For. Ecol. Manag. 1998, 110, 283-292. [CrossRef]

12. Hobbs, R.J.; Mooney, H. Vegetative regrowth following cutting in the shrub Baccharis pilularis ssp. consanguinea (DC) C.B. Wolf. Am. J. Bot. 1985, 72, 514-519. [CrossRef]

13. Bechtold, H.; Inouye, R. Distribution of carbon and nitrogen in sagebrush steppe after six years of nitrogen addition and shrub removal. J. Arid Environ. 2007, 71, 122-132. [CrossRef]

14. Fetcher, N. Effects of removal of neighboring species on growth, nutrients, and microclimate of Eriophorum vaginatum. Arct. Alp. Res. 1985, 7-17. [CrossRef]

15. Lett, M.S.; Knapp, A.K. Consequences of shrub expansion in mesic grassland: resource alterations and graminoid responses. J. Veg. Sci. 2003, 14, 487-496. [CrossRef] 
16. Potts, D.L.; Scott, R.L.; Bayram, S.; Carbonara, J. Woody plants modulate the temporal dynamics of soil moisture in a semi-arid mesquite savanna. Ecohydrology 2010, 3, 20-27. [CrossRef]

17. Facelli, J.M.; Temby, A.M. Multiple effects of shrubs on annual plant communities in arid lands of South Australia. Austral Ecol. 2002, 27, 422-432. [CrossRef]

18. Heinrichs, S.; Schmidt, W. Short-term effects of selection and clear cutting on the shrub and herb layer vegetation during the conversion of even-aged Norway spruce stands into mixed stands. For. Ecol. Manag. 2009, 258, 667-678. [CrossRef]

19. Rango, A.; Tartowski, S.L.; Laliberte, A.; Wainwright, J.; Parsons, A. Islands of hydrologically enhanced biotic productivity in natural and managed arid ecosystems. J. Arid Environ. 2006, 65, 235-252. [CrossRef]

20. Li, X.Y.; Hu, X.; Zhang, Z.H.; Peng, H.Y.; Zhang, S.Y.; Li, G.Y.; Li, L.; Ma, Y.J. Shrub hydropedology: Preferential water availability to deep soil layer. Vadose Zone J. 2013, 12. [CrossRef]

21. Peng, H.Y.; Li, X.Y.; Li, G.Y.; Zhang, Z.H.; Zhang, S.Y.; Li, L.; Zhao, G.Q.; Jiang, Z.Y.; Ma, Y.J. Shrub encroachment with increasing anthropogenic disturbance in the semiarid Inner Mongolian grasslands of China. Catena 2013, 109, 39-48. [CrossRef]

22. Zhang, S.Y.; Li, X.Y.; Peng, H.Y.; Zhang, Z.H. Infiltration pattern beneath shrub canopy and interspace grass patches in typical steppe ecosystems of Inner Mongolia, China. J. Earth Environ. 2012, 95, 1117-1125.

23. Moore, G.W.; Barre, D.A.; Owens, M.K. Does Shrub Removal Increase Groundwater Recharge in Southwestern Texas Semiarid Rangelands? Rangel. Ecol. Manag. 2012, 65, 1-10. [CrossRef]

24. Seyfried, M.S.; Wilcox, B.P. Soil water storage and rooting depth: key factors controlling recharge on rangelands. Hydrol. Process. 2006, 20, 3261-3275. [CrossRef]

25. Sala, O.; Golluscio, R.; Lauenroth, W.; Soriano, A. Resource partitioning between shrubs and grasses in the Patagonian steppe. Oecologia 1989, 81, 501-505. [CrossRef] [PubMed]

26. Havstad, K.M.; Gibbens, R.P.; Knorr, C.A.; Murray, L.W. Long-term influences of shrub removal and lagomorph exclusion on Chihuahuan Desert vegetation dynamics. J. Arid Environ. 1999, 42, 155-166. [CrossRef]

27. Rango, A.; Huenneke, L.; Buonopane, M.; Herrick, J.; Havstad, K. Using historic data to assess effectiveness of shrub removal in southern New Mexico. J. Arid Environ. 2005, 62, 75-91. [CrossRef]

28. D'Odorico, P.; Porporato, A. Soil moisture dynamics in water-limited ecosystems. In Dryland Ecohydrology; Springer: Dordrecht, Netherlands, 2006; pp. 31-46.

29. Bosch, J.M.; Hewlett, J.D. A review of catchment experiments to determine the effect of vegetation changes on water yield and evapotranspiration. J. Hydrol. 1982, 55, 3-23. [CrossRef]

30. Mainguet, M. Aridity. In Droughts and Human Development, 1st ed.; Springer: Berlin, Germany, 1999. [CrossRef]

31. Misson, L.; Tang, J.; Xu, M.; McKay, M.; Goldstein, A. Influences of recovery from clear-cut, climate variability, and thinning on the carbon balance of a young ponderosa pine plantation. Agric. For. Meteorol. 2005, 130, 207-222. [CrossRef]

32. Wuzhesiguleng; Liu, S.M.; Song, B.Y.; Yang, J.Y. Characteristics of Photosynthesis and Water Physio-ecology of Stipa Grandis. J. Inner Mong. Univ. (Nat. Sci. Ed.) 2015, 46, 262-269.

33. Kemp, P.R. Phenological patterns of Chihuahuan Desert plants in relation to the timing of water availability. J. Ecol. 1983, 71, 427-436. [CrossRef]

34. Tissue, D.; Wright, S. Effect of seasonal water availability on phenology and the annual shoot carbohydrate cycle of tropical forest shrubs. Funct. Ecol. 1995, 9, 518-527. [CrossRef]

35. Dreiss, L.M. The Role of Phenology in Invasive Plant Species Success in Temperate Forest Understories. Ph.D. Thesis, University of Connecticut, Storrs, CT, USA, August 2016.

36. Li, X.Y.; Zhang, S.Y.; Peng, H.Y.; Hu, X.; Ma, Y.J. Soil water and temperature dynamics in shrub-encroached grasslands and climatic implications: Results from Inner Mongolia steppe ecosystem of North China. Agric. For. Meteorol. 2013, 171, 20-30. [CrossRef]

37. Czarnomski, N.M.; Moore, G.W.; Pypker, T.G.; Licata, J.; Bond, B.J. Precision and accuracy of three alternative instruments for measuring soil water content in two forest soils of the Pacific Northwest. Can. J. For. Res. 2005, 35, 1867-1876. [CrossRef]

38. McGarigal, K.; Cushman, S.; Ene, E. FRAGSTATS: Spatial Pattern Analysis Program for Categorical and Continuous Maps. Available online: https:/ / www.umass.edu/landeco/research/fragstats/fragstats.html. (accessed on 23 January 2015). 
39. Wan, W.; Liu, X. The Observation Methods of Phenology in China; Science Press: Beijing, China, 1979; pp. 42-57.

40. Phillips, D.L.; Gregg, J.W. Source partitioning using stable isotopes: coping with too many sources. Oecologia 2003, 136, 261-269. [CrossRef] [PubMed]

41. West, A.G.; Patrickson, S.J.; Ehleringer, J.R. Water extraction times for plant and soil materials used in stable isotope analysis. Rapid Commun. Mass Spectrom. 2006, 20, 1317-1321. [CrossRef] [PubMed]

42. Phillips, D.L.; Gregg, J.W. IsoSource: Stable Isotope Mixing Model for Partitioning an Excess Number of Sources; Version 1.3.1; EPA: Washington, WA, USA, 2005.

43. Farquhar, G.D.; Hubick, K.T.; Condon, A.G.; Richards, A.R. Carbon isotope fractionation and plant water-use efficiency. In Stable Isotopes in Ecological Research; Rundel, P.W., Ehleringer, J.R., Nagy, K.A., Eds.; Springer: Berlin, Germany, 1989; pp. 21-40.

44. Yu, X.N.; Zhao, J.; Qi, Y.; Huang, Y.M.; Gong, J.R. Effects of soil moisture content on morphological and photosynthetic characteristics of Leymus chinensis and Medicago sativa. Acta Ecol. Sin. 2014, 32, 6067-6075.

45. Elliott, A.; Carlson, W. Effects of sheep grazing episodes on sediment and nutrient loss in overland flow. Soil Res. 2004, 42, 213-220. [CrossRef]

46. Chu, J.M. Study on Water Utility of Plant in Arid Area. Ph.D. Thesis, Chinese Academy of Forestry, Beijing, China, August 2007.

47. Duniway, M.C.; Snyder, K.A.; Herrick, J.E. Spatial and temporal patterns of water availability in a grass-shrub ecotone and implications for grassland recovery in arid environments. Ecohydrology 2010, 3, 309-314. [CrossRef]

48. Dodd, M.; Lauenroth, W.; Welker, J. Differential water resource use by herbaceous and woody plant life-forms in a shortgrass steppe community. Oecologia 1998, 117, 504-512. [CrossRef] [PubMed]

49. Li, F.; Zhao, W.Z.; Liu, H. The Response of Aboveground Net Primary Productivity of Desert Vegetation to Rainfall Pulse in the Temperate Desert Region of Northwest China. PLoS ONE 2013. [CrossRef] [PubMed]

50. Fan, Y.; Li, X.Y.; Wu, X.C.; Li, L.; Li, W.; Huang, Y.M. Divergent responses of vegetation aboveground net primary productivity to rainfall pulses in the Inner Mongolian Plateau, China. J. Arid Environ. 2016, 129, 1-8. [CrossRef]

51. Fang, Q.M.; Gong, D.Y.; Mao, R. Changes of Daily Precipitation of China in Wintertime during the Last 46 Years. Sci. Geogr. Sin. 2007, 27, 711-717.

52. D'Odorico, P.; Fuentes, J.D.; Pockman, W.T.; Collins, S.L.; He, Y.; Medeiros, J.S.; DeWekker, S.; Litvak, M.E. Positive feedback between microclimate and shrub encroachment in the northern Chihuahuan desert. Ecosphere 2010. [CrossRef]

53. Wepener, J.-P. The Control of Stoebe Vulgaris Encroachment in the Hartbeesfontein Area of the North West Province. Ph.D. Thesis, North-West University, Mahikeng, South Africa, 2007. 